\title{
PAX3/FOX01 Fusion Gene
}

National Cancer Institute

\section{Source}

National Cancer Institute. PAX3/FOXO1 Fusion Gene. NCI Thesaurus. Code C99712.

A fusion gene ( 3.2 kb) that results from a chromosomal translocation $\mathrm{t}(2 ; 13)(\mathrm{q} 35 ; \mathrm{q} 14)$

which fuses intron 7 of the PAX3 gene with intron 1 of the FOXO1 gene. This

rearrangement is associated with alveolar rhabdomyosarcoma. 